\title{
Two Symmetrical Squarylium Cyanine Dyes: Synthesis, Photophysics and Antifungal Activity in Saccharomyces cerevisiae ${ }^{+}$
}

\author{
Vanessa S. D. Gomes ${ }^{1,2}$, João C. C. Ferreira ${ }^{2,3,4}$, Renato E. F. Boto ${ }^{5}$, Paulo Almeida ${ }^{5}$, Maria João M. F. Sousa ${ }^{3,4}$, \\ Lucinda V. Reis ${ }^{1}$ and M. Sameiro T. Gonçalves ${ }^{2, *}$
}

Citation: Gomes, V.S.D.; Ferreira, J.C.C.; Boto, R.E.F.; Almeida, P.; Sousa, M.J.M.F.; Reis, L.V.; Gonçalves, M.S.T. Two Symmetrical Squarylium Cyanine Dyes: Synthesis, Photophysics and Antifungal Activity in Saccharomyces cerevisiae. Chem. Proc. 2021, 3, 106. https://doi.org/10.3390/ecsoc-2408423

Academic Editors: Julio A. Seijas and M. Pilar Vázquez-Tato

Published: 14 November 2020

Publisher's Note: MDPI stays neutral with regard to jurisdictional claims in published maps and institutional affiliations.

Copyright: (c) 2020 by the authors. Licensee MDPI, Basel, Switzerland. This article is an open access article distributed under the terms and conditions of the Creative Commons Attribution (CC BY) license (http://creativecommons.org/licenses /by/4.0/).
1 Centre of Chemistry-Vila Real (CQ-VR), Department of Chemistry, University of Trás-os-Montes and Alto Douro, Quinta de Prados, 5001-801 Vila Real, Portugal; ID6971@alunos.uminho.pt (V.S.D.G.); lucinda.reis@utad.pt (L.V.R.)

2 Centre of Chemistry (CQ-UM), Department of Chemistry, University of Minho, Campus of Gualtar, 4710-057 Braga, Portugal; ID7351@alunos.uminho.pt

3 Centre of Molecular and Environmental Biology (CBMA), Department of Biology, University of Minho, Campus of Gualtar, 4710-057 Braga, Portugal; mjsousa@bio.uminho.pt

4 Institute of Science and Innovation for Bio-Sustainability (IBS), University of Minho, Campus of Gualtar, 4710-057 Braga, Portugal

5 Health Sciences Research Centre (CICS-UBI), University of Beira Interior, Av. Infante D. Henrique, 6201-506 Covilhã, Portugal; rboto@ubi.pt (R.E.F.B.); pjsa@ubi.pt (P.A.)

* Correspondence: msameiro@quimica.uminho.pt

+ Presented at the 24th International Electronic Conference on Synthetic Organic Chemistry, 15 November- 15 December 2020; Available online: https://ecsoc-24.sciforum.net/.

\begin{abstract}
Two squarylium cyanine dyes were synthesized and characterized by the usual analytical techniques, including Vis-NIR absorption and emission spectroscopy. Their antifungal activity was evaluated, through the obtention of minimum inhibitory concentration (MIC) values, using yeasts of the species Saccharomyces cerevisiae as a biological model.
\end{abstract}

Keywords: squarylium cyanine dyes; antifungal activity; NIR fluorescence dyes; fluorescent probes; fluorochromophores

\section{Introduction}

Squarylium cyanine dyes are 1,3-disubstituted compounds, owning a resonance stabilized zwitterionic structure, which presents a central four-membered ring derivative of squaric acid (3,4-dihydroxycyclobut-3-en-1,2-dione) and two electron donor groups at the end of the polymethine chain [1-4]. This class of compounds presents good photochemical stability, narrow and intense absorption, emission bands in the visible to near infrared region, a high molar extinction coefficient and good photoconductivity [5-8]. In the last few years, interest in these polymethine dyes has been increasing, specially because of their technological and biological applications, mainly as organic solar cell sensitizers [9-11], as markers of several biomolecules [12-14] and as photosensitizers (PS) for photodynamic therapy (PDT) [15-17]. Depending on the application intended, changes in their structures can be made in order to improve the required properties.

Considering all these facts, two symmetrical squaraine cyanine dyes derived from indolenine and benz[e]indole possessing ester groups in the chains attached to nitrogen atoms were synthetized. The structural elucidation of the dyes, as well as of their precursors, was performed using the usual analytical techniques. Fundamental photophysics studies in ethanol, in addition to determination of the antifungal activity of the dyes were carried out. 


\section{Results and Discussion}

\subsection{Synthesis of squarylium cyanine dyes $\mathbf{1}$ and $\mathbf{2}$}

Condensation reaction between 1-(2-carboxyethyl)-2,3,3-trimethylindol-1-ium bromide or 1-(2-carboxyethyl)-2,3,3-trimethylbenzo[e]indol-1-ium bromide, as quaternary ammonium salts, and 3,4-dihydroxycyclobut-3-ene-1,2-dione, using $n$-butanol and toluene at reflux in a Dean-Stark system, gave squarylium cyanine dyes $\mathbf{1}$ and 2, respectively (Figure 1). The blue solids isolated with yields of 17\% (1) and 59\% (2) were characterized by standard spectroscopic methods. It should be noted that during the condensation reaction mentioned above, the esterification of the carboxylic groups of the $\mathrm{N}$-alkyl chain of the quaternary salts occurred, as can be confirmed by analysis of ${ }^{1} \mathrm{H}$ and ${ }^{13} \mathrm{C}$ NMR spectra of both dyes.

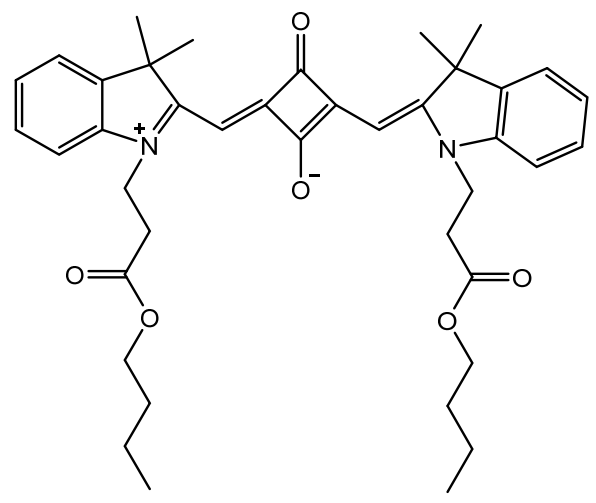

1

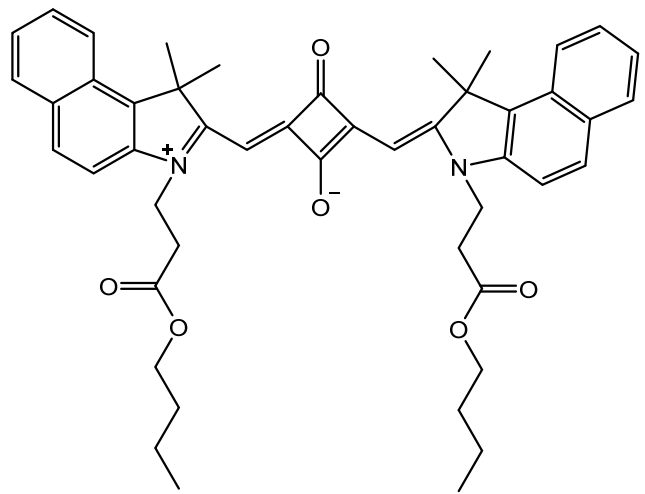

2

Figure 1. Chemical structures of the synthetized and tested squarylium cyanine dyes $\mathbf{1}$ and $\mathbf{2}$

The ${ }^{1} \mathrm{H}$ NMR spectrum of the cyanine 1 showed aromatic protons from the heterocyclic system at $\delta 7.08-7.35 \mathrm{ppm}$ and the spectrum of cyanine 2 at $\delta 7.42-8.20 \mathrm{ppm}$. The methine protons appeared at $\delta 5.93 \mathrm{ppm}$ for 1 and at $\delta 6.00 \mathrm{ppm}$ for 2 as a singlet of two protons. As expected, the ${ }^{1} \mathrm{H}$ NMR spectra of synthesized dyes $\mathbf{1}$ and $\mathbf{2}$ presented only a sole methine proton signal, which is in accordance with the symmetrical character of these molecules. Methylene protons of the presented compounds appeared as sextets, quintets, triplets, and broad singlets at $\delta 1.28-1.31 \mathrm{ppm}\left(\mathrm{N}\left(\mathrm{CH}_{2}\right)_{2} \mathrm{COOCH}_{2} \mathrm{CH}_{2} \mathrm{CH}_{2} \mathrm{CH}_{3}\right), \delta$ 1.52-1.54 ppm $\left(\mathrm{N}\left(\mathrm{CH}_{2}\right)_{2} \mathrm{COOCH}_{2} \mathrm{CH}_{2} \mathrm{CH}_{2} \mathrm{CH}_{3}\right), \quad \delta \quad 2.82-2.90$ ppm $\left(\mathrm{NCH}_{2} \mathrm{CH}_{2} \mathrm{COO}\left(\mathrm{CH}_{2}\right)_{3} \mathrm{CH}_{3}\right), \delta 4.05 \mathrm{ppm}\left(\mathrm{NCH}_{2} \mathrm{CH}_{2} \mathrm{COO}\left(\mathrm{CH}_{2}\right)_{3} \mathrm{CH}_{3}\right)$ and $\delta 4.34-4.47 \mathrm{ppm}$ $\left(\mathrm{N}\left(\mathrm{CH}_{2}\right)_{2} \mathrm{COOCH}_{2} \mathrm{CH}_{2} \mathrm{CH}_{2} \mathrm{CH}_{3}\right)$. The terminal methyl groups of chain linked to the nitrogen atom emerged at $\delta 0.84-0.89 \mathrm{ppm}\left(\mathrm{N}_{(}\left(\mathrm{CH}_{2}\right)_{2} \mathrm{COO}\left(\mathrm{CH}_{2}\right)_{3} \mathrm{CH}_{3}\right)$, while the methyl groups of heterocyclic rings arise at $\delta 1.78$ and $2.07 \mathrm{ppm}\left(\mathrm{C}\left(\mathrm{CH}_{3}\right)_{2}\right)_{\text {. }}$.

The ${ }^{13} \mathrm{C}$ NMR spectra exhibited aromatic carbons in the form of four signals at $\delta$ 109.68-127.99 ppm, for cyanine 1 and six signals at $\delta 110.31-129.84 \mathrm{ppm}$ for cyanine 2 . Methyl groups of the molecules are presented at $\delta 13.70$ and $13.78 \mathrm{ppm}$ $\left(\mathrm{N}\left(\mathrm{CH}_{2}\right)_{2} \mathrm{COO}\left(\mathrm{CH}_{2}\right)_{3} \mathrm{CH}_{3}\right)$ and $\delta 26.95$ and $27.25 \mathrm{ppm}\left(\mathrm{C}\left(\mathrm{CH}_{3}\right)_{2}\right)$. Methine groups arise at $\delta$ 86.93 and $86.67(\mathrm{CH}=\mathrm{C}) \mathrm{ppm}$ and methylene groups of both compounds present very similar chemical shifts, emerging at $\delta \quad 19.12$ and 19.17 ppm

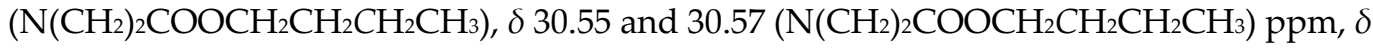
31.75 and $32.01 \mathrm{ppm}\left(\mathrm{NCH}_{2} \mathrm{CH}_{2} \mathrm{COO}\left(\mathrm{CH}_{2}\right)_{3} \mathrm{CH}_{3}\right), \delta 39.42$ and $39.52 \mathrm{ppm}$ $\left(\mathrm{NCH}_{2} \mathrm{CH}_{2} \mathrm{COO}\left(\mathrm{CH}_{2}\right)_{3} \mathrm{CH}_{3}\right)$, and $\delta 65.25$ and $65.26 \mathrm{ppm}\left(\mathrm{N}\left(\mathrm{CH}_{2}\right)_{2} \mathrm{COOCH}_{2} \mathrm{CH}_{2} \mathrm{CH}_{2} \mathrm{CH}_{3}\right)$.

\subsection{Fundamental Photophysics of Dyes $\mathbf{1}$ and $\mathbf{2}$}

The absorption and fluorescence properties of the synthetized squarylium cyanine dyes 1 and $\mathbf{2}$ were evaluated in ethanol. The relative fluorescence quantum yields were determined using zinc phthalocyanine as a reference ( $\Phi_{\mathrm{F}}=0.17$ in dimethylformamide) [18] and using an excitation wavelength of $580 \mathrm{~nm}$. All the results are shown in Table 1. 
Table 1. Fundamental photophysical data of synthesized dyes $\mathbf{1}$ and $\mathbf{2}$ in ethanol.

\begin{tabular}{cccccc}
\hline \multirow{2}{*}{ Dye } & \multicolumn{5}{c}{ Ethanol } \\
\cline { 2 - 6 } & $\lambda_{\text {abs }}(\mathbf{n m})$ & $\varepsilon\left(\mathbf{M}^{-\mathbf{1}} \mathbf{c m}^{-\mathbf{1}}\right)$ & $\lambda_{\text {em }}(\mathbf{n m})$ & $\boldsymbol{\Phi}_{\text {F }} \mathbf{( \% )}$ & $\Delta \lambda \mathbf{~ ( n m ) ~}$ \\
\hline $\mathbf{1}$ & 631 & 385,684 & 639 & 81 & 8 \\
$\mathbf{2}$ & 663 & 324,591 & 672 & 26 & 9 \\
\hline
\end{tabular}

Cyanine 2 showed maximum absorption wavelength $\left(\lambda_{\text {abs }}\right)$ and maximum emission wavelength $\left(\lambda_{\mathrm{em}}\right)$ superior to cyanine 1 , which is in line with expectations, due to the introduction of another fused aromatic ring in the heterocyclic base. Regarding the molar extinction coefficient $(\varepsilon)$, the highest value is attributed to compound $\mathbf{1}\left(385,684 \mathrm{M}^{-1} \mathrm{~cm}^{-1}\right)$, as well as the highest fluorescence quantum yield $\left(\Phi_{\mathrm{F}}\right)$ value $(81 \%)$.

The normalized absorption and emission spectra of cyanines $\mathbf{1}$ and $\mathbf{2}$ in ethanol are shown in Figures 2 and 3, respectively.

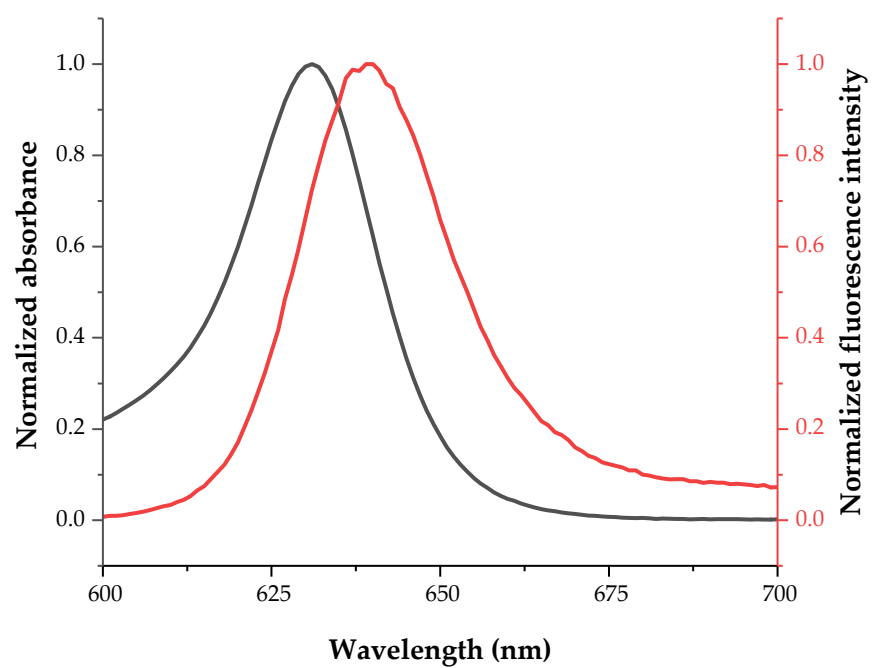

Figure 2. Normalized absorption (dark line) and fluorescence spectra (red line) of squarylium cyanine dye 1 in ethanol.

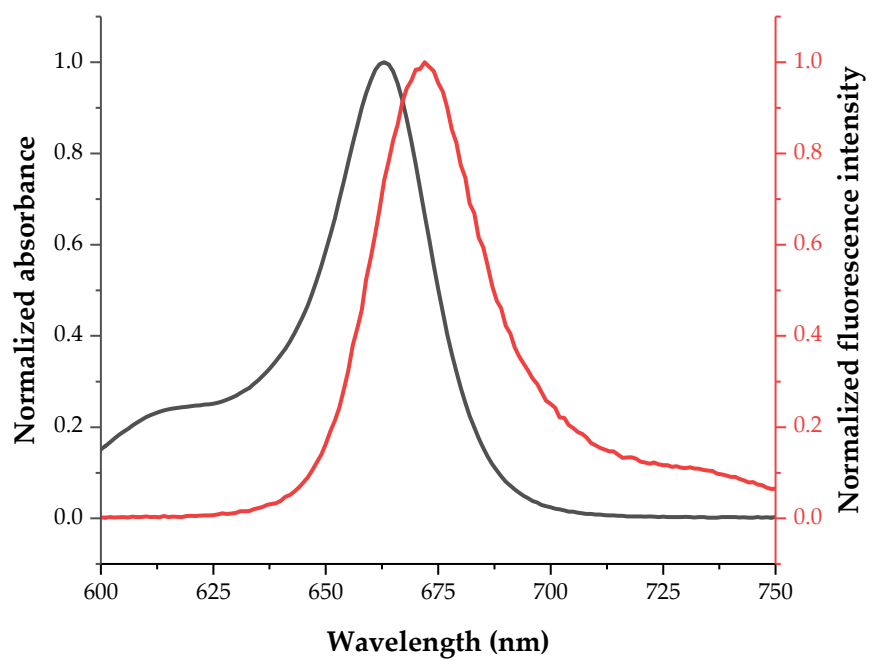

Figure 3. Normalized absorption (dark line) and fluorescence spectra (red line) of squarylium cyanine dye $\mathbf{2}$ in ethanol. 


\subsection{Antifungal Activity of Dyes $\mathbf{1}$ and $\mathbf{2}$}

The antifungal activity of squarylium cyanine dyes $\mathbf{1}$ and $\mathbf{2}$ against yeasts of the species Saccharomyces cerevisiae was determined and presented through the minimum inhibitory concentration (MIC) value. The value of Log P was also determined and corresponds to an estimated measure of the compounds hydrophobicity by calculating the partition between membranes and aqueous media (Table 2).

Table 2. Minimum inhibitory concentration (MIC) values obtained for dyes $\mathbf{1}$ and $\mathbf{2}$ in the antifungal activity tests against Saccharomyces cerevisiae.

\begin{tabular}{ccc}
\hline Dye & MIC $(\mu \mathbf{M})$ & Log $\mathbf{P}$ \\
\hline $\mathbf{1}$ & $>100$ & 1.70 \\
$\mathbf{2}$ & 50 & 4.02 \\
\hline
\end{tabular}

Cyanine 1 has a MIC value superior to $100 \mu \mathrm{M}$, while cyanine 2 displays better activity with MIC of $50 \mu \mathrm{M}$. These results indicate that the presence of the naphthalene instead of a benzene ring in the heterocyclic base seems to improve antifungal activity. Compounds with smaller Log P values are more soluble in water while compounds with higher values have greater affinity for membrane systems. Cyanine 2 was found to have a higher Log P value, which will be related to its greater antifungal activity.

\section{Experimental Section}

\subsection{Typical Procedure for the Synthesis of Dyes 1 and 2 (Illustrated for 1)}

1-(2-carboxyethyl)-2,3,3-trimethylindol-1-ium bromide $(0.400 \mathrm{~g}, 1.28 \mathrm{mmol})$ and 3,4-dihydroxycyclobut-3-ene-1,2-dione $(0.073 \mathrm{~g}, 0.640 \mathrm{mmol})$ in a mixture of $n$-butanol/toluene $(10 \mathrm{~mL}, 1: 1 \mathrm{v} / \mathrm{v})$, was stirred for $6 \mathrm{~h}$ at reflux in a Dean-Stark apparatus. Cold distilled water was added to the reaction mixture and after separation by decantation, the organic layer was dried with anhydrous $\mathrm{Na}_{2} \mathrm{SO}_{4}$ and the solvent removed under reduced pressure. After successive recrystallizations from $\mathrm{CH}_{2} \mathrm{Cl}_{2} / \mathrm{MeOH} /$ petroleum ether/ diethyl ether, 4-[(1-(2-butoxycarbonylethyl)-3,3-dimethyl-3H-indol-1-ium-2-

yl)methylene]-2-[(1-(2-butoxycarbonylethyl)-3,3-dimethylindolin-2-ylidene)methyl]-3-ox ocyclobut-1-en-1-olate (1) was obtained as a light blue solid $(0.059 \mathrm{~g}, 17 \%) .{ }^{1} \mathrm{H}$ NMR $\left(600.10 \mathrm{MHz}, \mathrm{CDCl}_{3}\right) \delta: 7.35(2 \mathrm{H}, \mathrm{d}, J=7.2 \mathrm{~Hz}, \mathrm{ArH}), 7.31(2 \mathrm{H}, \mathrm{t}, J=7.5 \mathrm{~Hz}, \mathrm{ArH}), 7.14(2 \mathrm{H}$, $\mathrm{t}, J=7.2 \mathrm{~Hz}, \mathrm{ArH}), 7.08(2 \mathrm{H}, \mathrm{d}, J=7.8 \mathrm{~Hz}, \mathrm{ArH}), 5.93(2 \mathrm{H}, \mathrm{s}, \mathrm{CH}=\mathrm{C}), 4.34(2 \mathrm{H}, \mathrm{bs}$, $\left.\mathrm{N}\left(\mathrm{CH}_{2}\right)_{2} \mathrm{COOCH}_{2} \mathrm{CH}_{2} \mathrm{CH}_{2} \mathrm{CH}_{3}\right), 4.05\left(4 \mathrm{H}, \mathrm{t}, J=6.6 \mathrm{~Hz}, \mathrm{NCH}_{2} \mathrm{CH}_{2} \mathrm{COO}\left(\mathrm{CH}_{2}\right)_{3} \mathrm{CH}_{3}\right), 2.82$ $\left(4 \mathrm{H}, \mathrm{t}, J=7.5 \mathrm{~Hz}, \mathrm{NCH}_{2} \mathrm{CH}_{2} \mathrm{COO}\left(\mathrm{CH}_{2}\right)_{3} \mathrm{CH}_{3}\right), 1.78\left(12 \mathrm{H}, \mathrm{s}, \mathrm{C}\left(\mathrm{CH}_{3}\right)_{2}\right), 1.54(4 \mathrm{H}, \mathrm{qt}, J=7.0 \mathrm{~Hz}$ $\left.\mathrm{N}\left(\mathrm{CH}_{2}\right)_{2} \mathrm{COOCH}_{2} \mathrm{CH}_{2} \mathrm{CH}_{2} \mathrm{CH}_{3}\right), 1.31\left(4 \mathrm{H}\right.$, st, $\left.J=7.4 \mathrm{~Hz}, \mathrm{~N}\left(\mathrm{CH}_{2}\right)_{2} \mathrm{COOCH}_{2} \mathrm{CH}_{2} \mathrm{CH}_{2} \mathrm{CH}_{3}\right)$, $0.89\left(6 \mathrm{H}, \mathrm{t}, J=7.5 \mathrm{~Hz}, \mathrm{~N}\left(\mathrm{CH}_{2}\right)_{2} \mathrm{COO}\left(\mathrm{CH}_{2}\right)_{3} \mathrm{CH}_{3}\right) \mathrm{ppm} .{ }^{13} \mathrm{C} \mathrm{NMR}\left(150.91 \mathrm{MHz}, \mathrm{CDCl}_{3}\right) \delta$ : 182.22, 180. 93, 170.88, 170.16, 142.08, $127.99(\mathrm{ArCH}), 124.12(\mathrm{ArCH}), 122.48(\mathrm{ArCH})$, $109.68(\mathrm{ArCH}), 86.93(\mathrm{CH}=\mathrm{C}), 65.25\left(\mathrm{CH}_{2}\right), 49.51 \mathrm{C}\left(\mathrm{CH}_{3}\right)_{2}, 39.40\left(\mathrm{CH}_{2}\right), 31.75\left(\mathrm{CH}_{2}\right), 30.57$ $\left(\mathrm{CH}_{2}\right), 27.25\left(\mathrm{C}_{\left.\left(\mathrm{CH}_{3}\right)_{2}\right),} 19.17\left(\mathrm{CH}_{2}\right), 13.78\left(\mathrm{CH}_{3}\right) \mathrm{ppm}\right.$.

\subsection{Antifungal Activity Assays}

Minimum inhibitory concentration of growth for the two compounds was determined using a broth microdilution method for the antifungal susceptibility against Saccharomyces cerevisiae yeasts. This assay was prepared in 96-well microplates using a cell concentration of $2.25 \times 10^{3}$ cells $/ \mathrm{mL}$, to which compounds were added at previously established concentrations. The stock solutions of compounds were prepared in dimethyl sulfoxide (DMSO) and then dissolved in RPMI (Roswell Park Memorial Institute) to obtain the desired concentrations per well. The plates were incubated at $30^{\circ} \mathrm{C}$ for $48 \mathrm{~h}$, after which the absorbance at $640 \mathrm{~nm}$ was read, using a microplate photometer. The obtained values allowed the determination of MICs, which correspond to the lowest concentration of compound that causes a growth inhibition of at least $80 \%$ when compared to a control. 
Five concentrations of each dye were tested, each in triplicate and in three independent assays.

\section{Conclusions}

Two squarylium cyanine dyes were successfully synthesized and characterized. Photophysical studies in ethanol showed maxima absorption and fluorescence emission wavelengths between $631-672 \mathrm{~nm}$ and fluorescence quantum yields of $81 \%$ and $26 \%$, being the highest value attributed to the cyanine $\mathbf{1}$ derived from 2,3,3-trimethylindolenine. Both cyanine dyes revealed antifungal activity, although dye 2 derived from 1,1,2-trimethyl-1H-benz[e]indole showed the best result with a MIC value of $50 \mu \mathrm{M}$.

To increase the antifungal capacity of the presented dyes, tests are being carried out using an LED irradiance system with an appropriate wavelength. The results have been quite promising, indicating that this type of dyes may be used as antifungal agents.

Author Contributions: Conceptualization, V.S.D.G., J.C.C.F., L.V.R. and M.S.T.G.; methodology, V.S.D.G. and J.C.C.F.; validation, R.E.F.B., P.A., L.V.R. and M.S.T.G.; formal analysis, V.S.D.G., J.C.C.F., R.E.F.B., P.A. and L.V.R.; investigation, V.S.D.G., J.C.C.F. and L.V.R.; resources, R.E.F.B., P.A., M.J.M.F.S., L.V.R. and M.S.T.G.; data curation, V.S.D.G., J.C.C.F., R.E.F.B., P.A., L.V.R. and M.S.T.G.; writing-original draft preparation, V.S.D.G.; writing-review and editing, V.S.D.G., R.E.F.B., P.A., L.V.R. and M.S.T.G.; visualization, L.V.R. and M.S.T.G.; supervision, L.V.R. and M.S.T.G.; project administration, L.V.R. and M.S.T.G.; funding acquisition, R.E.F.B., P.A., M.J.M.F.S., L.V.R. and M.S.T.G. All authors have read and agreed to the published version of the manuscript.

Institutional Review Board Statement: Not applicable.

Informed Consent Statement: Not applicable.

Data Availability Statement: Not applicable.

Acknowledgments: We thanks to Fundação para a Ciência e Tecnologia (FCT) and FEDER (European Fund for Regional Development)-COMPETEQREN-EU for financial support to the research centers CQ/UM (UIDB/00686/2020), CBMA (UID/BIA/04050/2020), CQ/VR (UID/QUI/UI0616/2019) and CICSUBI (POCI-01-0145-FEDER-007491), as well as $\mathrm{PhD}$ grants to J.C.C.F. (SFRH/BD/133207/2017) and V.S.D.G. (UMINHO/BD/43/2016).

Conflicts of Interest: The authors declare no conflict of interests.

\section{References}

1. Reis: L.V.; Serrano, J.P.; Almeida, P.; Santos, P.F. The synthesis and characterization of novel, aza-substituted squarylium cyanine dyes. Dyes Pigments 2009, 81, 197-202.

2. Yano, S.; Hirohara, S.; Obata, M.; Hagiya, Y.; Ogura, S.; Ikeda, A.; Kataoka, H.; Tanaka, M.; Joh, T. Current states and future views in photodynamic therapy. J. Photochem. Photobiol. C 2011, 12, 46-67.

3. Sreejith, S.; Carol, P.; Chithra, P.; Ajayaghosh, A. Squaraine dyes: A mine of molecular materials. J. Mater. Chem. 2008, 18, 264274.

4. Pisoni, D.S.; Abreu, M.P.; Petzhold, C.L.; Rodembusch, F.S.; Campo, L.F. Synthesis, photophysical study and BSA association of water-insoluble squaraine dyes. J. Photochem. Photobiol. A 2013, 252, 77-83.

5. Martins, T.D.; Pacheco, M.L.; Boto, R.E.; Almeida, P.; Farinha, J.P.S.; Reis, L.V. Synthesis, characterization and protein-association of dicyanomethylene squaraine dyes. Dyes Pigments 2017, 147, 120-129.

6. Liu, L.; Chen, J.; Ku, Z.; Li, X.; Han, H. Unsymmetrical squaraine sensitizers containing auxiliary arylamine donor for NIR-harvesting on dye-sensitized solar cell. Dyes Pigments 2014, 106, 128-135.

7. Park, J.; Viscardi, G.; Barolo, C.; Barbero, N. Near-infrared Sensitization in Dye-sensitized Solar Cells. Chimia 2013, 67, 129-135.

8. Avirah, R.R.; Jayaram, D.T.; Adarsh, N.; Ramaiah, D. Squaraine dyes in PDT: From basic design to in vivo demonstration. Org. Biomol. Chem. 2012, 10, 911-920.

9. Al-horaibi, S.A.; Asiri, A.M.; El-Shishtawy, R.M.; Gaikwad, S.T.; Rajbhoj, A.S. Synthesis and characterization of new squaraine dyes with bis-pendent carboxylic groups for dye-sensitized solar cells. J. Mol. Struct. 2019, 1195, 850-858.

10. Chen, G.; Sasabe, H.; Igarashi, T.; Hong, Z.; Kido, J. Squaraine dyes for organic photovoltaic cells. J. Mater. Chem. A 2015, 3, 14517-14534. 
11. Fan, B.; Maniglio, Y.; Simeunovic, M.; Kuster, S.; Geiger, T.; Hany, R.; Nüesch, F. Squaraine Planar-Heterojunction Solar Cells. Int. J. Photoenergy 2009, 2009, 581068.

12. Gomes, V.S.D.; Gonçalves, H.M.R.; Boto, R.E.F.; Almeida, P.; Reis, L.V. Barbiturate squaraine dyes as fluorescent probes for serum albumins detection. J. Photochem. Photobiol. A 2020, 400, 112710.

13. Saikiran, M.; Sato, D.; Pandey, S.S.; Kato, T. Photophysical investigations of squaraine and cyanine dyes and their interaction with bovine serum albumin. J. Phys. Conf. Ser. 2016, 704, 012012.

14. He, Q.; Fan, X.; Sun, S.; Li, H.; Pei, Y.; Xu, Y. Highly selective turn-on detection of (strept)avidin based on self-assembled near-infrared fluorescent probes. RSC Adv. 2015, 5, 38571-38576.

15. Lima, E.; Ferreira, O.; Gomes, V.S.D.; Santos, A.O.; Boto, R.E.; Fernandes, J.R.; Almeida, P.; Silvestre, S.M.; Reis, L.V. Synthesis and in vitro evaluation of the antitumoral phototherapeutic potential of squaraine cyanine dyes derived from indolenine. Dyes Pigments 2019, 167, 98-108.

16. Lima, E.; Ferreira, O.; Silva, J.F.; Santos, A.O.; Boto, R.E.; Fernandes, J.R.; Almeida, P.; Silvestre, S.M.; Reis, L.V. Photodynamic activity of indolenine-based aminosquaraine cyanine dyes: Synthesis and in vitro photobiological evaluation. Dyes Pigments 2020, 174, 108024.

17. Friães, S.; Silva, A.M.; Boto, R.E.; Ferreira, D.; Fernandes, J.R.; Souto, E.B.; Almeida, P.; Ferreira, L.F.V.; Reis, L.V. Synthesis, spectroscopic characterization and biological evaluation of unsymmetrical aminosquarylium cyanine dyes. Bioorg. Med. Chem. 2017, 25, 3803-3814.

18. Ogunsipe, A.; Maree, D.; Nyokong, T. Solvent effects on the photochemical and fluorescence properties of zinc phthalocyanine derivatives. J. Mol. Struct. 2003, 650, 131-140. 